\title{
POLA PENDIDIKAN PESANTREN DALAM MEMBENTUK \\ KARAKTER SANTRI
}

\author{
Dudung Abdullah \\ dudungabdullah1607@gmail.com \\ Universitas Islam Al-Ihya Kuningan
}

\begin{abstract}
ABSTRAK
Pola pendidikan karakter yang diterapkan di pondok pesantren sangat beragam sesuai dengan metode atau konsep yang akan dicapai. Keberhasilan atau tidaknya pendidikan kakrakter tergantung sosok kiayi yang menjadi panutan. Santri sendiri yang menjadi objek diharapkan mampu memberikan solusi setiap permasalahan yang apabila dihadapi di kemudian hari. Keinginan kuat dan cita-cita tinggi menjadi satu dalam jiwa kepribadian, kepribadian inilah yang menjadi indicator kepribadian santri dalam menghadapi realita kehidupan.
\end{abstract}

Kata kunci : pendidikan, karakter, santri

\begin{abstract}
The term of character education which is applied in Islamic boarding school is various based on the method or concept that would be gain. The key characteristic education is based on the figure of Kiayi as main role model. The Santri themselves as object is hoped to be able give salutation in every problem which would be probably faced in the future. The desire and eagerness become one in the soul. This character becomes main indicator of student personality at traditional Muslim school to face the reality in life.
\end{abstract}

Key word: education, character, santri 


\section{PENGANTAR}

Pendidikan tertua di Indonesia adalah pesantren, Jika kita lihat benang merah ke belakang, bahwasanya pesantren merupakan warisan dari walisongo. Mereka membawa perubahan besar bagi tuntunan kehidupan manusia khusunya di Indonesia. Dimana Indonesia menjadi Negara muslim terbesar di Dunia. Hal ini mendorong bagi pemuka agama (kiyai) untuk melanjutkan estafet pendidikan pesantren. Pesantren adalah lembaga yang memiliki akar kuat dalam tuntunan kehidupan masyarakat baik social maupun budaya.Budaya-budaya yang tidak sesuai dengan ajaran islam dihilangkan,kemudian dirubah dengan metode baru yang sesuai dengan tuntunan al quran. Pesantren memiliki andil besar dalam pendidikan islam, meskipun sering kali kita mendengar ucapan-ucapan yang memojokkan pesantren, tetapi dalam realita kehidupan di masyarakat pesantrenlah yang memiliki peran penting dalam kehidupan.

Didalam pesantren ada beberapa aspek yang vital untuk menentukan santri yakni kiyai, masjid, kitab-kitab dan madrasah. Kiyai merupakan figure sentral yang memiliki peran penting untuk menentukan arah dan tujuan, dari segi ilmu dan pengetahuan tidaklah diragukan, sehingga memiliki pengaruh besar dalam kehidupan bermasyarakat. Hal ini dapat memberikan kontribusi bagi santri sendiri karena figure pemimpin atau kiyai yang dapat dijadikan ketauladanan. Maka dapat dianggap sebagai modal berharga dalam menanamkan pembiasaan para santri melaului proses belajar mengajar (muhaimin, $2002: 25$ )

Disiplin, bersungguh-sungguh dan pengawasan dari para kiyai merupakan bimbingan pendidikan nyata dilingkungan pesantren. Kemandirian dan kerjakeras, religious, kebersamaan, hormat, tanggung jawab, jujur dan ikhlas (Budiyanto, 2014:108)Merupakan realitas kehidupan pendidikan pesantren, dengan tujuan utama menciptakan santri yang memiliki budi pekerti dan kemandirian guna menghadapi kehidupan yang bermanfaat bagi dirinya maupun orang lain dimasa yang akan datang.

Dari alasan diatas, maka penulis mencoba untuk meneliti lebih dalam mengenai pola pendiddikan pesantren dalam membentuk karakter santri. Namun, 
selain itu mungkin akan muncul pertanyaan yang memaksa kita untuk menengok ke belakang, yaitu masihkan relevan karakter pendidikan di pesantren dijadikan sebagai acuan era globalisasi? Karena diadakan pesentren didalamnya memiliki mutiaramutiara yang kekal dan abadi,sehingga kita bisa menemukan berbagai cara untuk dapat dijadikan pegangan hidup.

\section{PEMBAHASAN}

Pendidkan pada dasarnya adalah proses pembelajaran yang terus-menerus yang bertujuan untuk mengembangkan potensi diri,baik kepribadian maupun keterampilan. Sebagaimana dijelaskan dalam Garis Besar Program Pembelajaran (GBPP) PAI, Pendidikan adalah usaha sadar dan terencana dalam menyiapkan peserta didik dengan tujuan persatuan dan kesatuan bangsa. Sedangkan karakter adalah kumpulan-kumpulan sifat seseorang yang menyatu dalam jiwa dan diaplikasikan dalam perilaku sehari-hari. Mulyasa mengatakan pendidikan karakter adalah pendidikan nilai atau value education yang dibangun sebagai pemahaman untuk menanamkan watak dan prilaku yang baik. Pendapat lain mengatakan otonomi dalam pengelolaan Pondok Pesantren dipegang oleh kiyai dalam mengelola santri sesuai dengan evaluasi yang dilakukan selama proses pembelajaran (Sumardi:2012). Jadi, pendidikan karakter adalah proses pembelajaran yang terus menerus dengan tujuan mengembangkan potensi diri agar menyatu dalam jiwa dan dilakukan bentuk perilaku. Hal ini menandakan pola pendidikan karakter di Pesantren yang diterapkan sangat beragam, tergantung apa target atau kurikulum yang akan dicapai.

Tujuan pendidikan karakter pesantren pada umunya menciptakan kader-kader penerus para ulama yang mempunyai jiwa-jiwa kepemimpinan yang berlandaskan hidup sesuai al-qur'an dan hadist.kedua pedoman ini,merupakan warisan dari nabi Muhammad SAW yang paling berharga bagi umat islam untuk dijadikan tuntunan ke arah yang benar dan lurus,bukan ke arah yang sesat.Sebagaimana argumentasi Mu'adz bin jabal ketika hendak diutus Rasulullah saw ke Yaman.Beliau akan melandaskan antara lain pada sunnah nabi saat menetapkan hukum suatu perkara 
yang dihadapinya dan nabi menyetujuinya dan membenarkan pendapat Mu'adz. Memiliki kebaikan karakter yang baik, dapat menunjukan kepribadian yang kuat dan mandiri dan mempunyai kemampuan intelektual (musqon, 2011:156). Hal inilah yang mendorong para kiyai atau yang terlibat dipesantren menjadikan pendidikan karakter dipesantren menjadi pokok utama dalam mengembangkan potensi yang dimiliki oleh seorang santri.

Zaman semakin berkembang, budaya tradisional mulai ada pergeseran. Tekhnologi semakin cangih, komunikasi mengalami perkembangan. Sedikit banyaknya perubahan dunia yang terjadi saat ini mempengaruhi kultur di lingkungan pesantren. Dulu pesantren hanya ditititk beratkan pada ta'lim (mengaji) dan ta'dzim (berkhidmat), namun saat ini santri dituntut untuk melek keterampilan lainnya. Hal inilah yang mendorong proses perubahan yang signifikan terhadap karakter pesantren, sebagaimana teori lain mengatakan menanamkan karakter perlu dilakukan secara fleksibel dan seiring dengan tuntunan dan perkembangan zaman, walaupun hal ini tidak semudah membalikan telapak tangan karena, karakter masing-masing santri berbeda-beda namun tidak menutup kemungkinan semua ini dapat dilakukan dengan mengedepankan pendidikan karakter yang terus menerus dan berkesinambungan.

Santri berasal dari bahasa india yaitu orang-orang yang paham tentang bukubuku suci agama hindu. Sementara menurut A.H Jhon menyebutkan istilah santri berasal dari bahasa tamil yang berarti guru mengaji. Dari beberapa pendapat diatas maka santri adalah orang-orang yang selalu belajar untuk mengetahui hukum-hukum agama islam yang sesuai dengan tuntunan al-qur'an dan hadist. Sebagaimana diketahui segala urusan yang berhubungan dengan peribadatan, muamalah, maupun yang lainnya harus benar-benar dikuasai dan dipahami untuk bekal menghadapi kehidupan yang akan datang. Karena seorang santri merupakan kader-kader para ulama yang notabenenya ulama adalah pewaris para nabi, dituntut untuk menjadikan santri sebagai penerus ulama di masyarakat.

Di dalam al-qur'an surat at-taubah ayat 122 yang berbunyi 


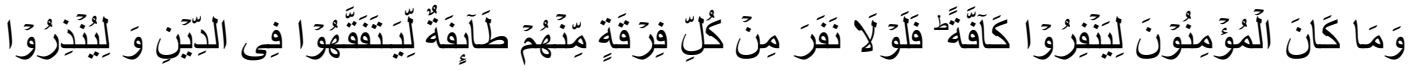

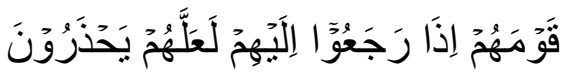

Artinya :

Dan tidak sepatutnya orang-orang mukmin itu semuanya pergi (ke medan perang). Mengapa sebagian dari setiap golongan di antara mereka tidak pergi untuk memperdalam pengetahuan agama mereka dan untuk memberi peringatan kepada kaumnya apabila mereka telah kembali, agar mereka dapat menjaga dirinya.

Dari ayat tersebut dijelaskan bahwasanya tidak semuanya orang-orang mukmin pergi ke medan perang diantara mereka. Ada yang memperdalamm ilmu pengetahuan agama dengan tujuan memberikan peringatan kepada kaumnya supaya kaumnya bisa menjaga dirinya. Ini membuktikan bahwa santri yang setiap hari mempelajari ilmu agama di pesantren mempunyai tujuan dan keyakinan tidak hanya dirinya namun masyarakatpun akan memperoleh keberkahan dan kebahagiaan di dunia dan akhirat. Sehingga santri diharapkan dapat menuju kesuksesan dan kebahagiaan,terutama di era globalisasi yang sangat kompleks dan penuh tantangan (Alhamudin, 2018:59).

Disamping itu juga, santri yang menetap di pesantren dituntut untuk mempunyai akhlakuk karimah yang menjadi suri tauladan dan keahlian dalam masalah segala bidang, Aklakul karimah inilah yang akan menjadi karakter bagi pribadi santri yang menggambarkan bagian dari keindahan islam. Selain mempunyai akhlakul karimah santripun harus mempunyai keahlian dalam berbagai bidang yang nantinya akan menjadikan bekal untuk ia berikhtiar dalam memenuhi kebutuhan hidupnya dan untuk mengembangkan agama islam karena islam tidak akan berkembang tanpa adanya mal (harta). Maka, ketika santri pulang dari pesantren harus menyesuaikan dengan lingkungan baru yang notabenenya dari berbagai kalangan yang berbeda.Seperti yang utarakan allport manusia adalah organisasi dinamis dari system psiko-fisik dalam individu yang turut menentukan cara-cara yang 
khas dalam menyesuaikan dengan lingkunganya. Maka inilah yang mendorong pesantren menjadikan sebagai lembaga yang mencetak kader-kader keumatan agar bisa menyelesaikan permasalahan - permasalahan yang dihadapi umat manusia. Al hasil kepribadian dan lingkungan pendidikan pesantren mempunyai andil besal dalam membentuk karakter seorang santri.

\section{KESIMPULAN}

Pendidikan karakter di Pesantren mempunyai pengaruh yang signifikan, guna membendung semakin majunya ilmu pengetahuan dan tekhnologi. Hal ini menjadi indicator berhasil tidaknya seorang pemimpin (kiyai) menjadi suri tauladan bagi para santrinya. Melalui kegiatan-kegiatan yang diadakan pesantren menjadikan salah satu cara untuk mencetak santri-santri yang mempunyai karakter baik sesuai dengan tuntutan al-qur'an dan hadis.

Disiplin dan bersungguh-sungguh dan pengawasan dari kiayi merupakan bimbingan pendidikan yang nyata dipesantren guna memberikan kontribusi bagi santri sendiri dan masyarakat dengan tujuan sebagai pembekalan untuk mengarungi kehidupan nyata dimasa yang akan datang. Santri sendiri yang menjadi objek dalam tatanan kehidupan pesantren menjadi perhatian focus bagi para kiayi dan sekitarnya. Oleh karena itu tidak relevan jika banyak masyarakkat sekitar yang sensitive terhadap keberadaan santri. Dari sinilah awal mula pembentukan karakter santri dalam menghadapi realita kehidupan, walauppun sebenarnya santri adalah pewaris para ulama dan ulama adalah pewaris nabi-nabi. 


\section{DAFTAR PUSTAKA}

Asy'Ari, 2011. Konsep Pendidikan Islam Implementasinya Dalam Tradisi Klasik Dan Propagasi Modern. Cetakan II. Jakarta: Rabbani Press

Azmi, Armaya. (2019). Penerapan Kaiah Fikih Tentang Niat "Al-Umuru bi Maqasidiha" dalam kasus hukum Tindak Pidana Pembunuhan. Jurnal Syariah dan Hukum Volume I (2). Juli 2019

Frimayanti, Ade Imelda. (2017). Implementasi Pendidikan Nilai dalam Pendidikan Agama Islam. Jurnal Pendidikan Islam Volume 8 (11). 2017.

Husaini, Adian. 2012. Pendidikan Islam Membentuk Manusia Berkarakter \& Beradab. Cetakan I. Jakarta: Cakrawala Publishing, dan Depok: Adabi Press.

Kamalia, Nu'tih. (2015). Konsep Ilmu Pendidikan Menurut Imam Al-Ghazali. Jurnal At-Ta'dib Volume 10 (1). Juni 2015

Marpaung, Irwan Malik. (2011). Konsep Ilmu dalam Islam. Jurnal At-Ta'dib Volume 6 No.2 Desember 2012.

Ngatiman, dkk. (2014). Menelaah Ilmu Hadis. Solo: Aqila

Setiawati, dkk. (2020). Pendidikan Karakter. Widina Bhakti Persada. ISBN: 978623-6608-50-0. Bandung.

Suharto, Babun. (2011). Dari Pesantren Untuk Umat: Reiventing Eksistensi Pesantren di Era Globalisasi. Surabaya/ Imtiyaz.

Wahyono, Joko (2012). Cara A.M.P.U.H Merebut Hati Murid. Samarinda: Esensi Erlangga Grup. 